\title{
Spiritual Organization: A Path to Organizational Sustainable Excellence
}

\author{
Mohi-Adden Yahya Al-Qutop ${ }^{1} \&$ Hussein Harrim ${ }^{1}$ \\ ${ }^{1}$ Faculty of Economics and Adm. Sciences, Business Administration Department, Applied Science Private \\ University, Amman, Jordan \\ Correspondence: Mohi-Adden Yahya Al-Qutop, Faculty of Economics and Adm. Sciences, Business \\ Administration Department, Applied Science Private University, Amman, Jordan. Tel: 962-795-573-233. E-mail: \\ alqutop@hotmail.com
}

Received: June 1, 2014

Accepted: June 25, 2014

Online Published: July 25, 2014

doi:10.5539/ibr.v7n8p168

URL: http://dx.doi.org/10.5539/ibr.v7n8p168

\begin{abstract}
In searching for quality and competitiveness, a steadily increasing number of governments and businesses have adopted "business excellence models" and "national quality awards" frameworks. Most of these were based on the American, European, Canadian or Japanese models. Organizational excellence is at crossroads today. Performance management systems and business excellence models and frameworks have given little to no consideration for social, environmental, human and ethical dimensions of organizational performance. Moreover, organizations have been confronting many unsurmountable challenges, changes and pressures that make it very necessary to look for an organizational excellence alternative, namely spiritual organization. This paper provides a framework for building spirituality-based organization that can harvest sustained excellence.
\end{abstract}

Keywords: organizational performance management, business excellence models, spiritual organization

\section{Introduction}

Recently, there has been a steadily increasing worldwide adoption of the so-called "business excellence models" and "national quality awards frameworks. Organizations and businesses have been confronting so many drastic changes, challenges and pressures, and has become a widely accepted fact that a business organization is no longer seen as merely an economic entity concerned only with maximization of profit and focusing on owners' interests. Instead an organization can have economic, social, environmental and even ethical impact. Thus, there has been a steadily worldwide concern with and recognition of the need for a reinvention of the ultimate mission and purpose of modern organizations. Businesses and organizations can, and should, play as powerful a gents of national progress and development, meet the needs and expectations of various stakeholders (in broadest sense), act as socially responsible citizens contributing to the well-being of people at community, national and even global levels, save and enhance the environment, and natural resources. One of the significant outcomes and results of steadily growing globalization, international business and world free trade agreements, is that the consequences and outcomes of organizations' operations and business behavior can, and will, cross national borders to other countries and continents, and in the end, will influence progress, prosperity, and well-being of the peoples of those countries.

All this strongly requires businesses and organizations to review radically their mission and purpose. This mission should extend beyond national borders, and national citizens. It can. and should, contribute to the progress and development of other countries, work for the common good, contribute to universal well-being, enhance democracy, freedom, respect human rights, dignity, sincerity, truthfulness, transparency, reinforce good ethical standards, emphasize collaboration more than competition, and contribute to better and meaningful world, and preserve and enhance environment and natural resources. Such challenging, ambitious and lofty goals and aims cannot be achieved under the current management practices and discourse, including performance management and organizational excellence. There is a strong need for a new business model a new organizational excellence model. Recently, the trend towards globalization has been the mainstream for many businesses, and it is expected to grow during the coming years, resulting in social, economic, financial, political and cultural difficulties and problems.

The criteria of current business excellence models and "national quality awards and frameworks" do not fully 
reflect an organization's performance at the social, environmental, and ethical fronts; it is the short-run economic performance that receives highest importance and emphasis. Any performance management system must have a long-term focus and address issues associated with the triple bottom line (issues of economic, social and environmental performance) (Searcy, 2011). A new business model is needed to enable organizations move steadily much closer to their ultimate purpose-betterment of peoples' lives, better and meaningful world, saving and enhancing environment and our earth planet and whatever lives on it. This paper presents on overview of the literature on business excellence models and national quality awards frameworks, their potentials and limitations, then highlighting the forces, challenges and pressures confronting organizations, followed by a clarification of spiritual organization, its potentials and limitations and a proposed framework for building sustainable spirituality-based organization.

\section{Literature Review of Evolution of Business Excellence Models}

The concept of business excellence is deeply rooted in Total Quality Management (TQM). TQM originally burst onto the global scene in 1984, with Rehder and Raiston's (1984) paper, the first to contain the phrase Total Quality Management (Mann et al, 2011). The Japanese quality management philosophy emerged early in the 1950s to form the roots of today's performance management theories and rules (Busi \& Betitci, 2006). The first globally known business excellence (BE) model was the Deming Prize introduced by the Union of Japanese Scientists and Engineers (JUSE) in 1951 (Union of Japan Scientists and Engineers, 2010). One of the devastating outcomes of the Second World War was a devastating stroke to Japanese economy. The Japanese manufacturing companies invited Dr. Deming, well-known American pioneer of quality control, to revitalize the Japanese economy through educating Japanese companies how to use statistical tools and techniques. Many companies adopted Deming's principles and rules focusing on customer satisfaction, continuous improvement and employees' participation. These companies achieved great jumps in both quality and productivity, which had great undesirable effects on American and Western Industries. These unexpected results led the JUSE to establish the "Deming Prize" in 1951 to honor Dr. W. E. Deming.

Interest in and awareness of importance of TQM continued to grow fast in the 1980s in USA and other countries, as governments and organizations saw TQM as the panacea that would address the decline of the manufacturing sector in the west (Mann et al, 2011). The next model of business excellence was the CAE Quality Award introduced by Canada in 1984 (National Quality Institute, 2007). The third model was the Malcolm Bridge National Quality Award (MBNQA), established by the United States of America (National Institute of Standards and Technology, 2009). In the year 1988, the Australian Business Excellence Framework (ABEF) become the fourth global known quality award. The fifth model was the European Foundation for Quality Management, introduced in 1991 and was renamed in the year 2004 as European Quality Award (European Foundation for Quality Management, 2010).

In the mid 1990s there was a change in terminology from "quality" to "total quality management" to organizational (or business) excellence in the west with the previously called "Quality" as "Total Quality Management Models" being renamed as Business Excellence Models (Adebango, 2001). The mid-1990s witnessed a "performance management metamorphosis of the Balanced Scorecard (BSC). By 2008, the BSC evolved from a measurement tool, to a management tool, to a system and then to a tool within a system, thus completing a full circle (Brudan, 2010).

In light of rabid globalization and high competition, more companies and governments throughout the world, especially Asia, developed and established their own customized quality awards, during the past twenty years. As of 2010, 86 countries are known to have a Business Excellence Award of some kind, with the idea of guiding their nation's organizations "toward operational results" (Mann et al., 2011). Talwar (2011b) has identified 100 excellence models and national quality awards being used by more than 82 countries, using the three globally recognized models-MBNQA of United states of America, EFQM European Quality Award, and Deming Prize-as references. There are some differences between the three global business excellence models, but there is considerable overlapping, with respect to criteria and weighting. The Deming Prize focuses on the dissemination of company-wide quality control, continuous improvement and relations with suppliers; its most important aspect is thorough application of statistical quality control techniques (Talwar, 2011a). The American MBNQA places emphasis on customer satisfaction. The principle behind its award criteria is that leadership drives activities (such as people, strategic planning, processes and information analysis), toward excellence in business results and customer satisfaction. The European EFQM focuses on benchmarking and satisfaction levels of customers, employees and community. The rationale for the EFQM model is the results-including customer, employees and society satisfaction-are achieved through leadership driving enablers, such as policy and strategy, people, partnerships and resources, and processes leading to excellence in business results (both financial and 
non-financial) (Talwar, 2011ba).

Evaluation criteria used by most of BEs/ NQAs are similar. The criteria common to most of the models and awards are nine criteria that can be classified into the following three groups (Talwar, 2011b):

1) Core Criteria-a must for survival-include: customer, people, and business results. These account for 50 percent of the score.

2) Internal environment criteria- differentiators in competitive environment-include: processes, leadership, strategic planning, and knowledge management. They account for 40 percent of the total score.

3) Goodwill criteria-ensuring sustenance-include: society, suppliers/partners. They account for 10 percent of the score.

\section{Potentials and Limitations of BEs and NQAs}

Saunders et al. (2008) identified the following reasons for adopting BEs and NQAs:

1) Provide a rigorous and sensible approach to identifying strengths and opportunities.

2) guide the organizations continuous improvement efforts.

3) Coordinate a range of initiatives.

4) provide an external measure of a successful organization.

5) allow companies to become "world-class".

6) Improve organizational performance.

7) Allow benchmarking against others in the same industry as well as those from other industries.

Research findings point that successful implementation of BE models has positive impacts on the firm's performance, financial and non-financial Curkovic et al., (2000); Douglas \& Judge (2001); Kaynak (2003); Oakland and Tanner (2008). In a study comparing the performance of awards winners with others, Jacob et al. (2004) found that 18 MBNQA attained higher profitability and assets utilization than others in the same industry. Another study conducted by Mann, Asebanjo and Tickle, in the year 2011, excellence models/ awards in five Asian countries, found that business excellence is highly regarded by a majority of the organizations as both an improvement tool and a management tool to support future competitiveness and long-term goals. Also, there was a strong culture of engagement and support for the business excellence award process. Awards were valued for their prestige and independent feedback (Mann et al, 2011). Competing for (and not necessarily winning) a business excellence award gives the company a heightened level of public recognition (Baizzo \& Bernardi; 2003; Khoo \& Tan, 2003). While there are few studies on the effectiveness of business excellence in Western countries, there are much fewer studies about Asian countries (Young \& Wilkinson, 2001; Arumugam et al., 2008).

However, other scholars have reported little to no evidence of improvements in firm's performance (Tuck, 2005a; Tuck, 2005b; Williams et al., 2006; Wilford, 2007; Grigg \& Mann, 2008). Another limitation is that the approval process is lengthy and can sometimes prevent companies from focusing on core activities (Lee, 2002). Another criticism is that the award structure is very rigid, resulting in companies struggling to match current processes with those in the award criteria (Mann et al., 2011). Despite the fact that award-winning companies have shown excellent financial results, there financial performance has not always been the best in industry (Talwar, 2011a). Most of the studies focus on business results in general and impact on the bottom line in particular. Thus, it is difficult to comment on benefits accrued to other stakeholders, moreover, there is a danger that organizations start focusing on winning the award rather than focusing on opportunities for making improvements (Talwar, 2011a). While BEM/NQAs emphasize organizations attaining excellence in "results" these models do not guarantee the sustainability of this excellence. This gives rise to the risk of using unethical means and practices to maximize the short-term goals, as has been witnessed recently in the global economic fiasco (Talwar, 2011a). An important limitation is related to the imbalance of the weighting and scoring of the various criteria. The goodwill criteria (social and environmental dimensions) account for only 10 percent of the score. It is that goodwill criteria that play a key role in attaining and maintaining sustainable results and growth (Talwar, 2011b).

Grigg and Mann (2008) conclude that although debates continue around the operational and financial benefits of competing for or obtaining business excellence awards, there is little doubt that competing for such awards ensures that firms concentrate on their processes, measurements and performance, and that winning the awards gives valuable publicity and commendation. 


\section{Challenges, Changes and Pressures Confronting Organizations}

During the past twenty years, organizations and management have been confronting many profound transformations, changes, challenges, pressures and demands, from within and without, at various levels and fronts. Such challenges changes and forces have driven for a steadily increasing interest into organizational spirituality. Among these changes and challenges are: a radical change in the nature of work, people looking for meaningful work beyond just earning money, which provides feeling of community among widely dispersed employees, and organizations are no longer considered as economic entities, but social and even spiritual (Konz \& Ryan, 1999) describing the work setting. Marques (2006) proclaims that stresses are prevailing and the organizational environment is unhealthy. Other forces pushing for workplace spirituality include: an increasing public interest in spirituality due to rising feeling of isolation, meaningless, and empty life, drastic changes in the nature of work as a result of a steadily growing globalization. Such changes included longer work hours, and at the same time demanding higher productivity for employees, organizational downsizing resulted in reduced for security, layoffs and increasing organizational conflicts (Ashmos \& Duchon, 2000; Adams \& Benzer, 2000; Kinjerske \& Skrypnek, 2006). Employees are looking for ways to counterbalance the stresses and pressures of a turbulent pace of life... people are looking for involvement and connection, for something meaningful in their lives, something beyond the Job (Robbins \& Coulter, 2005, p. 62). Many people look for the satisfaction of their spiritual needs, i.e., to be unique, to commune with something greater than themselves, to be useful, to be understood by others, and as to understand how they fit into greater context (Strack et al., 2002). Among the most important and compelling arguments the steadily increasing focus on workplace spirituality is " people look for ways to cope with the drastic social and business changes, and that global changes in values has brought an increasing interest in eastern philosophies and in spiritual needs and aspirations" (Giacalone et al., 2003). Three challenging issues, very relevant to organizational performance and excellence, have been placing steadily growing pressures and demands on organizations and managers, worldwide. These issues are: corporate social responsibility, environment and managerial ethics. The social economic view of social responsibility, which is widely advocated, says that managers' social responsibilities go beyond making profits to owners to include protecting and improving society's' welfare,.. Business's intentions go beyond its legal and economic obligations to do the right things and act in ways that help improve society because the organization feels it has an ethical responsibility to do so. ISO developed in 2010 standards for social responsibility (Known as ISO 26000) (Robbins et al., 2011: 95). "Green Organization", "green management", and "eco-friendly" organizations have gained global momentum and attention. Managers and organizations can, and should, strive hard to protect, preserve and enhance the natural environment. The increasing number of environmental disasters and destruction brought a new spirit of environmentalism to individuals, groups, and organizations throughout the globe, though with varying degrees. Increasingly, managers have begun to consider the impact of their organizations' operations and activities on the natural environment, which we call green management (Robbins et al., 2011: 98). The non-governmental International Organization for Standardization (ISO) has developed ISO 14000 (environmental management standards). Such standards can be used to evaluate green management actions and organizational commitment to improve its environmental performance toward environmental management excellence.

Last, but not least, is managerial and business ethics. Recently, fraud, bribery, theft, financial information misrepresentation, abuse of authority, and other unethical acts and behaviors have steadily widely proliferated, leading to many disastrous financial, economic and social outcomes. Hence, the need for enhancing managers' and employees' ethical behaviors is immediate and great.

During the last few years, a series of dramatic and catastrophic crises, challenges and events have confronted many parts of the world, which have had many significant impacts on governments, businesses and peoples' lives. In the year 2008, the United States of America was paralyzed by a catastrophic financial crisis, soon spread to reach many different parts of the globe, and which caused devastating financial, economic and social outcomes. Major public debt crisis hit a number of European Union countries, bringing them close to bankruptcy in 2011. Late in 2011, specifically in October, a group of protesters marched through New York streets heading toward "wall street", later, demonstration spread to other cities in the United States of America and many other countries in various continents. The issues that protesters stressed were: greater number of homeless, and jobless people, deteriorating health and education, escalating social injustice, the widening gap between the rich and the poor, global warming, Pollution etc.

One of the dramatic and unexpected events is the so-called "Arab Spring" in the year 2011. Millions of peoples in several Arab countries have demonstrated and protested throughout 2011-2103. Those "uprisings" loudly and strongly were demanding freedom, democracy, social justice, human dignity, jobs, better health care, education, 
and such. Eventually, a number of regimes and governments were overthrown.

\section{Spiritual Organization: A Path to Organizational Sustainable Excellence}

\subsection{The Need for Spiritual Organization}

Evolution of performance management and assessment, for most of the twentieth century, argues Seddon (2008), was driven by command and control and mechanistic thinking. An alternative approach is strongly needed: a system thinking and approach to performance management that promotes holistic, integrative approach, shifting measurement of performance from measurement for control and reward to measurement for learning. A similar view proclaimed by Brudan (2011), "Performance management frameworks have been slow to adapt to the challenges, changes and pressures confronting organizations...These frameworks still emphasize financial measures, short-term goals, and command and control approach, based on maintaining achievement of goals that are set by managers.

Most of business excellence models and national quality award frameworks, states (Talwar, 2011b), see "business results" as the ultimate goal. The writer adds " The pursuit of economic growth let to deterioration of physical environment, unsafe workplace, pollution, urban decay, discrimination against certain groups, unethical scandals and other social problems...there seems to be an imbalance between social and environmental dimensions and the focus of management and that results in unsustainable results and growth. (Searcy, 2011) proclaims that an organization's final purpose must focus on sustainability instead of profits, in order that organizations can cope with the dynamic competitive environment and respond to internal and external pressures....sustainability means adopting business strategies and activities that meet the needs of the enterprise and its stakeholders while protecting, sustaining and enhancing the human and natural resources. Similarly, (Allio, 2011) states "... when almost everyone in the world has been hurt by questionable corporate practices and their consequences, there is a strong need to articulate a new purpose of the firm, corporate survival of sustainability and innovation.

Thus, there is strong need for sustainability performance measurement systems that explicitly focus on the triple bottom line issues (social, economic and environmental issues) and the linkages between those issues, and explicit focus on the long-term view of the business performance (Searcy, 2011). Challenges, changes and pressures confronting organizations strongly urge for a radical transformation of organizational mission, vision, culture, leadership, management system and practices, core competences, and such. A new management model: a virtuous corporate and radical management practices that attain a balance between internal and external goals. Among the precepts that this model should follow:

1) Build a community and a culture that; (a) supports and rewards the pursuit of excellence in practice, catalyzed by continuous innovation; (b) celebrates corporate values such as: just purpose, authenticity, balance of power, and integrity; (c) develops systemic consciousness, from which social justice and ecological sensitivity will flow naturally (Allio, 2011).

2) Externally: Abandon the mindless quest for short-term profits; celebrate collaboration to higher priority than competition.

One of the greatest challenges facing leaders today, is the need to develop new business models that accentuate ethical leadership, employee well-being, sustainability, and social responsibility without sacrificing profitability (Fry \& Slocum Jr., 2008). The writers add, "What is required from top managers is to maximize at the same time the "People", "Planet", and "Profitability"...what is strongly needed, they add, is a spiritual leadership and organization. Thaker (2011) strongly advocates a similar view, as he states: neo-liberalism dominates current management principles and practices, and thus focus is on individual self-interest ... with short-run narrow focus on maximizing profits and owners' interests...This mode of functioning results in socially and environmentally dysfunctional organizations, and leading organizations away from sustainability. An alternative is a spiritual model of business (spiritual organizational).

\subsection{Conceptualization of Spiritual Organization}

As many writers have been attracted to organizational spirituality, may conceptualizations and perspectives of organizational spirituality have been proposed, they have differences, but also considerable overlapping. Workplace spirituality is defined as "seeking one's ultimate purpose in life, to develop strong connections with others at work, and to recognize compatibility between a person's values an organizational values" Mitroff and Denton (1999). A brief definition is the recognition an individual has an inner life that enhances and is enhanced by having a meaningful work within context of community Duchon (2000).

An organization is spiritual, says Milliman et al. (2003), is one that enables an individual to develop strong 
connections to others, and to have consistency between one's core beliefs and the values of the organization.

A more elaborate conceptualization, spirit at work involves: a meaningful work that has a higher purpose, an awareness of compatibility between an individual's values and work, a feeling of being authentic, a feeling of strong interconnectedness with others and a sharing a common propose, and a positive feeling of vitality, transcendence and experience of joy (Kinjerski \& Skryphek, 2004).

"Workplace spirituality incorporates those values that lead to a sense of transcendence and interconnectedness such that workers experience fulfillment on the job. This sense of transcendence- of having a calling through one's work (vocationally), and the need for membership, community, or social connection provide the foundation for a theory of workplace spirituality" (Fry \& Slocum Jr., 2008).

Each of those definitions, and others, is incomplete, but not inaccurate. Upon examining the various conceptualizations and definitions, it can be said that workplace spirituality or organization spirituality involves the following themes and notions:

1) Employees engage in meaningful work/ job.

2) An employee feels having a meaningful job, serving a higher purpose in life with greater responsibility, involving contributing to welfare of others, and the common good.

3) A clear shared vision and mission, focusing on global well-being common good, etc.

4) Integration/ alignment of personal development and long-term personality with job performance.

5) Admit that every individual has talents and creative capacities and potentials. She/he must be allowed and encouraged to unleash and nurture such potentials and capacities, towards reaching full potentials.

6) Help an employee develop a sense of call through one's work (vocationally) and experience a feeling of joy and bliss.

7) Emphasizing a full awareness of the need and work for "Sustainable growth/ development" which requires a full recognition of the limited resources, sincere interest inproticting, saving and enhancing our planet and what lives on it. (Mitroff \& Denton, 1999; Ashmas \& Duchon, 2000; Milliman et al, 2003, Giacalone \& Jurkiewicz, 2003; Kinjersk \& Skrypnek, 2004; Reyo \& Pina, Cohna, 2008; Duchon \& Plowman, 2005; Fry \& Slocum ,Jr, 2008; Weymes, 2005).

\subsection{Potential of Organizational Spirituality}

Empirical research on workplace spirituality is still limited, but literature provides increasing evidences that workplace/ organizational spirituality can yield great benefits including, but not limited to: improving productivity, service quality and retention, generate corporate sustainability (Fawcett et al, 2008); greater productivity, commitment, creativity, increased positive human health and psychological and spiritual well being, and provide a source of sustainable competitive advantage, reduced absenteeism, turnover and stress, (Fry \& Slocum Jr, 2008), generates corporate sustainability (Lips-Wiersman \& Ver Kataraman, 2006), spiritual oriented companies achieved higher net earnings, return on investment, and shareholder value, workplace spirituality enhances corporate social and ethical responsibility and employee's morale, job satisfaction, job involvement and organizational commitment.

\subsection{Building Organizational Spirituality}

Certainly, building and maintaining workplace/ organizational spirituality is a very challenging and demanding process, because of the lack for agreed on measurement(s) and definition of the phenomenon. Moreover, workplace spirituality is multi-facet, multi-dimensional. Not to mention that the prevailing organizational setting presents an obstacle to transforming an organization into spiritually-oriented one, this should not discourage any attempts in this direction. The proposed framework for building spirituality- based organization encompasses five interacting "Core Pillars": Organization mission/ vision, spiritual leadership, organization culture, human development, and organizational design.

\subsubsection{Organizational Mission/Vision}

A clear compelling, understandable and acceptable (by organizational members) organizational mission and vision statements is very important. The mission statement focuses on its purpose, why it exists, what the organization and whom it serves. The vision and mission together define the philosophy and core values of organization (Giacalone et al., 2003). Mission and Vision statements should clearly and explicitly incorporate genuine and constant commitment to maximize simultaneously the triple bottom line or people, planet and profitability; adopt sustainable models and strategies that will yield positive economic, social environmental 
outcomes and results. The ultimate purpose of the organization should focus on common good, community and social welfare and interests, and better and meaningful world. When an organization extends its focus to encompass society, and the environment, the members of the organization share the dream of the organization, and share ownership of its values (Weymes, 2005). Mission statements should show and demonstrate a commitment to adopt business activities and make decisions that contribute to the common good with a consideration for social justice and environmental protection. (Thaker, 2009).

\subsubsection{Organizational Culture}

What is strongly needed is an organizational culture that is ethical, innovative, customer- responsive and promotes workplace spirituality (Robbins and Coulter, 2005: 60). Corporate scandals and unethical decisions and practices have been steadily rising at unprecedented rate through the various countries, which led to devastating economic, human, social, cultural and environmental consequences. This have created within people the perception that organizations are amoral, corrupt, unethical and lack a sense of social responsibility (Fry \& Slocum, Jr., 2008. Social and environment dimensions have been consistently ignored and given little importance in most of BEs and NQAs, because there is a lack of focus on human values which give rise to the risk of the use of unethical practices to maximize short-run gains (Talwar, 2011b). Likewise, Svensson and Wood (2011), argue that management and business still seek to maximize profits, and that profit doesn't guarantee that business practices undertaken by organizations to achieve this profit are in the best interests of the society, such that they are ethical.

Literature provides valuable different perspectives about core values and cultural characteristics of spiritual organization, with considerable overlapping. Among those core values and characteristics are: an altruism whereby leaders and followers share genuine concern, appreciation for each other, thereby creating a sense of membership (mutual understanding and acceptance) (Giacolone et al., 2003); trust, benevolence, justice, respect, humanism, meaningful work, hope, dignity and honesty (Jurkiwicz \& Giacalone, 2004); altruistic values of respect, fairness, honesty, care, compassion which will create trust-based culture (Fry \& Slocum, Jr, 2008).

Along with those values, there is an urgent and critical need to institutionalize a culture that espouses and emphasizes high ethical climate and high ethical standards (Robbins and Coulter, 2005: 60). There is a need, to establish a framework of corporate business ethics encompassing ethical structures, processes and performance measures within and across organizations (Syensson \& Wood, 2011).

\subsubsection{Leadership}

The key to maintain an organizational culture is the philosophy and values of leaders. Leaders' spirituality also influences the selection and socialization of employees, and through mission statement (Kons \& Ryan, 1990). Warren Bennis (2002) urges leaders to create meaningful world for others as well as a sense of community at work. Pfeffer (2003) identified the following leadership practices to build spirit at work:

1) Places mission and values ahead shareholder profits.

2) Encourage independent and decision making responsibility.

3) Encourage people to utilize and develop their gifts and skills.

4) Use group-based reward system and recognition.

5) Adopt self-managed teams.

6) Help people to meet their family and other non-ware obligation.

Among the essential key process to spiritual leadership are:

1) Develop a vision whereby leaders and followers experience a sense of meaningful life that make a difference.

2) Establishes an organizational culture that stresses altruism whereby leaders and followers have sense of membership, feel understood and appreciated, and a genuine mutual care, concern and appreciation.

\subsubsection{Human Resource Development}

Workplace spirituality is a learnable behavior therefore human resource management should try to include it in their training programs (Ashmas \& Duchan, 2000): The organizational long-term capabilities and competitiveness can suffer very much from a lack of investment in developing employee's knowledge and skills, inspiring workplace climate requires competence along with affirmation and belonging.

(Fry, 2003) Helping employees to express and achieve full potential demand developing people's knowledge and skill much beyond job requirements. Employee's developments should include knowledge, values, attitudes 
useful for the whole organization, and other's lives, as well.

Hence, organizations must recognize the value of knowledge and learning, and provide all necessary opportunities, support and encouragement to help employees emotionally, ethically and spiritually, namely to develop and grow as a whole person. An important path to employees' development and growth is employees' empowerment. Empowerment is a multi-dimensions concept including (Spreitzer, 1995; Thomas \& Velthouse, 1990):

1) Meaning of work (value of work purpose);

2) Autonomy/ independence;

3) Impact of organizational outcomes;

4) Competence (self-efficacy).

A critical factor in whether spiritual-based management practices result in improved performance involves empowering employees with the capability to participate in developing and implementing organizational vision... the reason for this, is that a key aspect of spirituality is that all people should seek to reach their full potentials and empowering employee is the only way individuals can attain their fullest sense of growth and contribution (Neck \& Milliman, 1994). Empowerment (true liberty) allows and encourages an employee to look for what may benefit the whole organization, rather than being concerned with specific job assignment only. (Thaker, 2009).

\subsubsection{Organization and Job Design}

The present organization structures are rigid and present a barrier to cultural change which is very essential to transform present organizations into spiritual ones. In fact present structures help the present culture rather than help change it (Kons \& Ryan, 1999). Creating, an organic, adaptive, flexible, flat structure is badly needed to in order that the pillars-discussed above-of spiritual organization can be developed and maintain led. What is needed is structured characterized by low formalism, low specialization, cross- functional and hierarchical teams, free and smooth communication, greater degree of decentralization, closer contacts with all stakeholders including the community and broader society.

Job design is a critical element/dimension of organization design. Higher motivation, job satisfaction and performance are among significant outcomes of well-designed jobs. According to Job Characteristics Model (JCM), these are five core job characteristics which determine how much a job is motivating. These characteristics are: skill variety, task identity, task significance, autonomy; and feedback. With these characteristics available, an employee can experience three critical psychological states: meaningfulness, responsibility and knowledge of result (Garge \& Rastogi, 2006).

An important aspect in job design is the need to design jobs in such a way to allow and require an employee to communicate and interact with others inside and outside the organization (such as customers, suppliers, etc). This may require expanding the use of job design on teams rather than individuals. Team work provides for interaction which creates a feeling of belonging and connectedness which is an important aspect of spirituality. A spiritual climate can also be promoted through: reasonable workload and hours, flexible work schedules, allowing more leisure and free time to engage in other activities, minimum risk of illness, reasonable stress, healthy safe place, on-site facilities, health and nutrition education, etc.

Each of the above-discussed "so-called" "core pillars" can help partially develop a spiritual organization. Since those "core pillars" are interdependent and interacting, therefore, in order to get sustainable and effective results, changes should include simultaneously as many as possible of those "core pillars". However, it must start with radical shift in the mission and vision of an organization. However, building and maintaining a spiritual organization is a very challenging, complicated, many-faceted process that requires constant stead fastness, commitment and involvement of all organizational members.

\section{Conclusions and Future Research}

Current business excellence models (BEs) and National Quality Awards (NQAs) have been basically developed in line with conventional management discourse and practices. Business organizations are being considered as basically economic entities. Therefore management still focuses on achieving highest profits, focusing on owner's interests and short-run goals. Many challenges, changes and pressures from different sources and levels have been facing management and organizations. A critical challenge is an increasing world-wide pressure and demand that organizations should play an active role in national economic and social development, to improve human well-being for peoples at community, national and even global levels , contribute to universal well-being, 
meaningful world and save, protect and enhance our earth planet to make it better and safe place to live on. Underpinning the literature is that management should focus on simultaneously maximizing the so-called triple bottom line, or "People", "Planet", Profitability" or long-run/sustainable positive social, environmental and economic outcomes and results. BEs and NQAs have not been adapted to accommodate those, challenges, trends and issues. An alternative approach that has been presented in this paper is a spiritual organization. The presented framework identifies the main themes and notions of spirituality-based organization, and the "core pillars" for building a spiritual organization.

Further theoretical and empirical research is still needed to help build and maintain spiritual organizations, leading to organizational sustainable excellence. Respond is still required building a spiritual to build a well-established theory of workplace spirituality. There is a strong need to agree on clear, empirical and operational conceptualization/ definition and on a set of measures. Further theoretical research is needed to address whatever gaps or shortcomings of the presented framework, and to establish its reliability and validity further empirical research must be carried out.

\section{Acknowledgement}

The authors are grateful to the Applied Science Private University, Amman, Jordan, for the financial support granted to cover publication fee of this research article.

\section{References}

Adebanjo, D. (2001). TQM and business excellence: is there really a conflict? Measuring Business Excellence, 5(3), 37-40. http://dx.doi.org/10.1108/13683040110403961

Allio, R. J. (2011). Reinventing management purpose: the radical and virtuous alternatives. Strategy and Leadership, 39(4), 4-11. http://dx.doi.org/10.1108/10878571111147341

Antony, Job. (2010). Measuring organizational performance and organizational excellence of SMEs-Part1. Measuring Business Excellence, 14(2), 3-11. http://dx.doi.org/10.1108/13683041011047812

Ashmos, D., \& Duchon, D. (2000). Spirituality at work: a conceptualization and measure. Journal of Management Inquiry, 9(2), 134-45. http://dx.doi.org/10.1177/105649260092008

Bennis, W. G. (2002). Crucibles of leadership. Harvard Business Review, 80, 39-48.

Biazzo, S., \& Bernardi, G. (2003). Organizational self- assessment options: a classification and conceptual map for SMEs. International Journal of Quality and Reliability Management, 20(8), 881-900. http://dx.doi.org/10.1108/02656710310493616

Brurdan, A. (2010). Rediscovering performance management: systems, learning and integration. Measuring Business Excellence, 14(1), 109-123. http://dx.doi.org/10.1108/13683041011027490

Busi, M., \& Betitci, U. (2006). Collaborative performance management: present gaps and future research. International Journal of Productivity and Performance management, 55(1), 7-25. http://dx.doi.org/10.1108/17410400610635471

Curkovic, S., Vickery, S., \& Droge, C. (2000). Quality-related action programs: their impact on quality performance and firm performance. Decision Science, 31(4), 885-905. http://dx.doi.org/10.1111/j.1540-5915.2000.tb00947.x

Douglas, T. J., \& Judge, W. Q. (2001). Total quality management implementation and competitive advantage: the role of structural control and exploration. Academy of Management Journal, 44(1), 158-69. http://dx.doi.org/10.2307/3069343

Duchan, D., \& Plowman, D. (2005). Nurturing the spirit at work: impact on work unit performance. The Leadership Quarterly, 16, 807-33. http://dx.doi.org/10.1016/j.leaqua.2005.07.008

Escrig, A. B., Bou, I. C., \& Roca, V. (2001). Measuring Relationship between total quality management and sustainable competitive advantage: a resource-based view. Total Quality Management, 12(7-8), 932-38. http://dx.doi.org/10.1080/09544120100000018

European Foundation for Quality Management (EFQM). (2010). Excellence Award. Retrieved from http//www.efqm. lorgl

Fawcett, S., et al. (2008). Spirituality and Organization culture: Cultivating the ABCs of an inspiring workplace. International Journal of Public Adminsitratiion, 31, 420-38. http://dx.doi.org/10.1080/01900690701590819

Fry, L. W. (2003). Toward a theory of spiritual leadership. The Leadership Quarterly, 14, 693-727. 
http://dx.doi.org/10.1016/j.leaqua.2003.09.001

Fry, L., \& Slocum, Jr. J. (2008). Maximizing the triple bottom line through spiritual leadership. Organizational Dynamics, 37(1), 86-96. http://dx.doi.org/10.1016/j.orgdyn.2007.11.004

Garge, P., \& Rastogi, R. (2006). New model of job design: motivating employees' performance. The Journal of Management Development, 25(6), 572-87. http://dx.doi.org/10.1108/02621710610670137

Giacalone R., et al. (2013). From advocacy to science: the next steps in workplace spirituality research. Retrieved from http://www.tarleton.edu-fry//SLTPaloutziar.Final.rtf

Giacalone, R., \& Jurkiewicz, C. (2003). Toward A Science of workplace Spirituality. In Giacalone et al. (Eds.), The Handbook of Workplace Spirituality and Organizational Performance. New York: M. E. Sharp.

Grigg, N., \& Mann, R. (2008). Rewarding excellence: an international study into business excellence award processes. Quality Management Journal, 15(3) 26-40.

Jacob, R., Madu, C. N., \& Tang, C. (2004). An empirical assessment of the financial performance of Malcolm Baldrige Award winners. International Journal of Quality and Reliability Management, 21(8), 897-914. http://dx.doi.org/10.1108/02656710410551764

Jurkiewicz, C., \& Giacalone, R. (2004). A values framework for measuring the impact of workplace spirituality on organizational performance. Journal of Business Ethics, 49(2), 129-42. http://dx.doi.org/10.1023/B:BUSI.0000015843.22195.b9

Kaynak, H. (2003). The relationship between total quality management practices and their effects on firm performance. Journal of Operations Management, 21(4), 405-35. http://dx.doi.org/10.1016/S0272-6963(03)00004-4

Khoo, H. H., \& Tan, K. C. (2003). Managing for quality in the USA and Japan: difference between MBNQA and JQA. The TQM Magazine, 15(1), 14-24. http://dx.doi.org/10.1108/09544780310454402

Kinjerski, V., \& Skrypnek, B. (2006). Measuring the intangible development of the spirit at work. Paper presented at the sixty-five annual meeting of the Academy of Management, Atlanta, GA.

Konz, G., \& Ryan, F. (1999). Maintaining an organizational spirituality: no easy task. Journal of Organizational Change Management, 12(3), 200-210. http://dx.doi.org/10.1108/09534819910273865

Lee, P. (2002). Sustaining business excellence through a framework of best practices in TQM. The TQM Magazine, 14(3), 142-49. http://dx.doi.org/10.1108/09544780210425883

Lips-Wiersma, M., \& Nilakant, V. (2006). Purpose beyond profit, toward a spiritual foundation for corporate social responsibility. Retrieved from http//www.Ebbf.Org/ publications

Mann, R., Adebanjo, D., \& Tickle, M. (2011). Deployment of business excellence in Asia: an exploratory study. International Journal of Quality Reliability Management, 28(6), 604-627. http://dx.doi.org/10.1108/02656711111141184

Milliman, J., et al. (2003). Workplace Spirituality and employee work attitudes: an exploratory empirical assessment. Journal of Organizational Change Management, 16(4), 426-47. http://dx.doi.org/10.1108/09534810310484172

Mitroff, I., \& Denton, E. (1999). A spiritual audit of Corporate America: a hard look at spirituality, religion and values in the workplace (1st ed.). San Fransisco, Jossey-Bass Publishers.

Najm, N., \& Al- Rifa'e, Gh. (2008). Spirituality in the workplace: field study of a sample of firms in Amman, Jordan. Jordan Journal of Business Administration, 4(1), 64-88.

National Institute of Standards and Technology. (2009). 2009-2010 criteria for performance excellence. National Quality Program, Baldrige. Retrieved from http://badrige.nist.gov/

National Quality Institute. (2007). Canada Awards for Excellence. Retrieved from http://www.nqi.ca/caeawards/

Oakland, J. S., \& Tanner, S. J. (2008). The relationship between business excellence and performance-an empirical study using Kinji's leadership excellence model. Total Quality Management, 19(7-8), 733-49. http://dx.doi.org/10.1080/14783360802159402

Pfeffer, J. (2003). Business spirit: management practices that sustain values. In Giacalone, R., \& Jurkiewicz, C. (Eds.), The Handbook of Workplace Spirituality and Organizational Performance (pp. 29-45). New York, Sharp. 
Rego, A., \& Pinae Cohna, M. (2008). Workplace spirituality and organizational commitment: an employee work attitude. Journal of Organizational Change Management, 21(1), 53-75. http://dx.doi.org/10.1108/09534810810847039

Robbins, S., \& Coulter, M. (2005). Management (8th ed.). Upper- Saddle River, New Jersey: Pearson Prentice-Hall.

Saunders, M., Mann, R. S., \& Grigg, N. P. (2008). Utilization of business excellence models: Australian and international experience. The TQM Magazine, 20(6), 651-63. http://dx.doi.org/10.1108/17542730810909392

Searcy, C. (2011). Updating corporate sustainability performance measurement systems. Measuring Business Excellence, 15(2), 44-56. http://dx.doi.org/10.1108/13683041111131619

Spreitzer, G. M. (1995). Psychological empowerment in the workplace: dimensions, measurement and Validation. Academy of Management Journal, 38(5), 1442-64. http://dx.doi.org/10.2307/256865

Svensson, G., \& Wood, G. (2011). A conceptual framework of corporate and business ethics across Organizations. The Learning Organization, 18(1), 21-35. http://dx.doi.org/10.1108/09696471111095975

Talwar, B. (2011a). Business excellence models and the path ahead. The Total Quality Journal, 23(1), 21-35.

Talwar, B. (2011b). Comparative study of framework, criteria and criterion weighting of excellence models. Measuring Business Excellence, 15(1), 49-65. http://dx.doi.org/10.1108/13683041111113240

Thaker, K. B. (2009). Approaches to spirituality in business. Journal of Human Values, 15(2), 185-198. http://dx.doi.org/10.1177/097168581001500208

Thompson, W. D. (2000). Can you train people to be spiritual? Training and Development, 54(12), 18-19.

Tuck, C. (2005a). A quality award and stock market reaction: evidence from Malaysia. Total Quality Management and Business Excellence, 16(6), 681-91. http://dx.doi.org/10.1080/14783360500077328

Tuck, C. E. (2005b). A quality award and stock market: evidence from the European Union. Total Quality Management and Business Excellence, 16(8/9), 979-89. http://dx.doi.org/10.1080/14783360500163128

Union of Japanese Scientists and Engineers. (2010). The Deming Prize. Retrieved from http//www.juse.or.jp/e/c/eming/index.html

Weymes, E. (2005). Organizations which make a difference: a philosophical argument for the people-focused organization. Corporate Governance, 5(2), 142-58. http://dx.doi.org/10.1108/14720700510562721

Wilford, S. (2007). The limits of award incentives: the (non-)relationship between awards for quality and organizational performance. Total Quality Management and Business Excellence, 18(3), 333-49. http://dx.doi.org/10.1080/14783360601152608

Williams, R., Bertsch, B., van Der Wiele, A.,Van Iwarden, J., \& Dale, B. (2006). Self- assessment against business excellence models: a critique and perspective. Total Quality Management and Business Excellence, 17(10), 1287-300. http://dx.doi.org/10.1080/14783360600753737

\section{Copyrights}

Copyright for this article is retained by the author(s), with first publication rights granted to the journal.

This is an open-access article distributed under the terms and conditions of the Creative Commons Attribution license (http://creativecommons.org/licenses/by/3.0/). 